\title{
LOS JUDÍOS DE LA ALMUNIA DE DOÑA GODINA, VILLA ARAGONESA DE SEÑORÍO, EN LA SEGUNDA MITAD DEL SIGLO XV *
}

ENCARNACIÓN MARÍN PADILLA

CSIC. Madrid

Baylo

Este apellido que aparece en judíos residentes en el lugar de Almonacid de la Sierra, lo llevó en La Almunia, en los años que abarca este estudio, un solo judío, Salamon Baylo, pero las noticias que la documentación aporta sobre él son escasas. Vivió Salamon Baylo en unas casas de la judería, que lindaban con las de Juce Taboch y de su mujer Mira Nazir en $1488^{380}$; y era dueño, además, de una viña en La Carrera la Glera ${ }^{381}$. Salamon Baylo fue uno de los asistentes a la reunión de la aljama que tuvo lugar el 3 de mayo de 1483 y a la del 11 de abril de 1486, como se ha visto.

\section{Çarfati}

Llevó este apellido en la villa Sento Çarfati, alias Barbamplo, sastre de profesión, que estuvo casado con Mira. Vivió el matrimonio en unas casas de la judería, que lindaban con la sinagoga, con casas de la cofradía de los judíos y con carrera pública; y eran dueños, también, de una viña en El Plano.

La primera noticia de Sento que proporciona la documentación de los años que abarca este estudio, alude a un poder general que, el 7 de octubre de 1489, dio Sento al pelaire Ángel Marco para

* Continuación de Sef XLIX (1989), 135-152 y 263-306, y L (1990), 85-127.

380 L.A.APN., Miguel Contín, 1488, fol. 12.

381 Dicho notario, 1490, fol. 24, donde sólo aparece el apellido Baylo. 
demandar y recibir cualquier cantidad que le debiera Antón Gonzálvez, batanero del lugar de Tobed, para otorgar albarán de lo recibido y para pleitos ${ }^{382}$.

El 29 de septiembre del año siguiente, Sento compró la viña citada, libre de cargas, a Domingo Gómez y a su mujer María Domingo por cien sueldos, que el matrimonio otorgó haber recibido ${ }^{383}$. El mismo día de la compra, Sento y su mujer Mira recibieron en comanda del escudero Ochona de Ortubia, alcalde de Calatorao, cincuenta sueldos, la mitad de lo que pagaron por la viña; respondieron de ellos con todos sus bienes, en especial con sus casas y la propiedad recién adquirida ${ }^{384}$.

Los abusos cometidos contra propiedades de los judíos tras la promulgación del edicto de expulsión, su posterior publicación y durante los días que precedieron al destierro, fueron un hecho, y el caso de Sento Çarfati uno de ellos. A Sento le habían «seydo furtadas" cuatro camisas suyas, cuatro de su mujer, cuatro de su hijo, doce de sus hijas y dos cojines sin fundas, uno morisco y otro con un "liston bermexo". Para poder recuperar las ropas, el 18 de julio de 1492 Sento, sin revocar otros procuradores, nombró como tales a Miguel de Matas y a Martín Rasera -este último y Jaime, hermano de Miguel, eran los comisarios reales de la expulsión-, para demandar y recibir en su nombre, cada uno por sí o juntos, las prendas sustraídas y para intervenir en pleitos, cuestiones y demandas, civiles y criminales ${ }^{385}$.

El poder general a pleitos dado por Sento Çarfati a dos cristianos de la villa, resulta interesante por dos motivos. Primero, porque contrasta con la petición del alamin de Mesones, a través de su procurador, a los comisarios reales de la expulsión para que procedieran con justicia en el abuso que intentaba contra su propiedad Abraham Arruet; y porque contrasta, también, con el abuso de Acach Abenforna, Johanan Frances y Juce Çuri con respecto a los bienes de dos mujeres cristianas muy pobres, una viuda y su hija. Y segundo, porque proporciona datos, aunque no nombres, sobre los

${ }^{382}$ Dicho notario, 1489, fols. 47-47v. El apellido Çarfati aparece, también, en judíos de Calatayud.

${ }^{383}$ Dicho notario, 1491 , fols. $79-79 v$.

384 Dicho notario y año, fols. $79 v-80$.

${ }^{385}$ Dicho notario, 1492 , fols. $79 v-80$. 
hijos de Sento y Mira, quizá un niño y tres niñas, posiblemente menores de edad, si cada miembro de la familia tenía el mismo número de camisas.

No se sabe, sin embargo, cuáles fueron los motivos que movieron a Sento a vender al día siguiente de hacer el poder, concretamente el 19 de julio, todos sus bienes muebles e inmuebles a su mujer Mira, a Semahon Carillo y a Alazar Ferrer, vecinos como él de la villa, por ochocientos sueldos que otorgó haber recibido ${ }^{386}$. ¿Pensaba Sento partir antes que su mujer e hijos o irse sólo él y dejar a éstos en la villa? ¿Se trataba de una venta ficticia para evitar pagos a deudores? ¿Intentaba impedir emparamientos de bienes por orden de los comisarios, a causa de deudas?. Nada se sabe, todo son conjeturas; pero sí parece que, entre sus planes, estaba abandonar la villa y partir con los demás judíos al destierro.

\section{Carillo}

El apellido lo llevaron en la villa los judíos Jehuda, su hijo Juce, otro Juce, sastre - hijo de Jaco Carillo que estuvo casado con Aljohar Cohen y que había muerto en los años que abarca este estudio ${ }^{387} \longrightarrow$, Salamon, Semahon y su hijo Acach ${ }^{388}$.

De Jehuda Carillo sólo consta que era tejedor y que actuó como testigo instrumental el 14 de febrero de $1492{ }^{389}$, y de su hijo Juce, que actuó como su padre el 11 de noviembre de $1489{ }^{390}$ y que, al parecer, tuvo el mismo oficio que él.

\footnotetext{
${ }^{386}$ Dicho notario y año, fols. 80v-81.

387 Jaco Carillo había sido amigo de Fernando de Tarazona, tamborino de Arándiga. El 30 de agosto de 1489 en Calatayud, contó Caçon Haym, de Arándiga, que conoció a dicho tamborino y que lo vio comer, estando sano, carne y aves degolladas por judíos, el "Jueves de la Cena" y beber vino, presenciando la bendición, en casa de Jaco (Z.AAT., leg. 18, $\mathrm{n}^{2} 6$, fol. 3v). El propio Fernando confesó, el 5 de abril de 1490 en Zaragoza, que comió en bodas de judíos en La Almunia y que, cuando tenía dieciséis años, estuvo allí tañendo un día de Semana Santa y comió con los judíos de sus carnes y aves, no en su mesa ni en viernes ni sábado; también tomó pan cenceño porque era la pascua de los judíos, pero no por ceremonia (dicho leg. y $\mathrm{n}^{\mathbf{Q}}$, fol. $8 \mathrm{v}$ ).

${ }^{388}$ Hubo un rabí Mosse Carillo que tuvo casas en la villa, pero que residía en el lugar de Arándiga.

${ }^{389}$ Dicho notario, 1492, fol. 18.

390 Dicho notario, 1489, fol. 56v.
} 
Hay que tener en cuenta, sin embargo, que cuando la documentación al referirse a un Juce Carillo no especifica si se trataba del hijo de Jehuda o del de Jaco, el estudioso no puede saber a cuál de ellos se refiere y corre el peligro de atribuir hechos a uno, que quizá pertenezcan al otro. En el caso de los dos judíos llamados Juce Carillo, he atribuido todas las referencias -excepto la anterior, porque se indica - al hijo de Jaco, aun sabiendo que puedo equivocarme en parte, menos en los casos donde se indica su filiación.

Parece que la situación económica de Juce Carillo, hijo de Jaco, no fue muy boyante, a tenor de las noticias que la documentación aporta sobre los primeros años que abarca este estudio y que tuvieron su origen en el otorgamiento de un instrumento notarial al que he de referirme en primer lugar. Juce Carillo había sido dueño de unas casas en la judería, que lindaban con las de Lorente Just, con carrera pública, con un callizo y con «los adobares»; y de una viña en Candenavas y dos en El Plano.

El 21 de marzo de 1483, Juce había vendido sus tres viñas, sus casas con los "vaxiellos vinarios et olearios" y los bienes que hubiera en ellas, además de todos sus otros bienes, derechos, acciones, etc., a don Ximeno de Urrea, vizconde de Biota ${ }^{391}$, que le pagó por todo dos mil sueldos ${ }^{392}$, según se dijo.

Dos meses después, concretamente el 27 de mayo de 1483, Juce, que había asistido a la reunión de la aljama del día 3, ratificó todos los actos en los que hubieran intervenido sus procuradores Galacián de León, Diego de Gotor, Juan Alonso y Jaime Tornero, notarios causídicos de Zaragoza, y volvió a otorgarles poder general ${ }^{393}$.

El hecho de que Juce ratificara a sus procuradores a pleitos y les volviera a dar poder general, de que hasta pasados dos años el nuevo propietario no tomara posesión de las casas compradas y de que, al parecer, fuera apresado, induce a pensar que la venta pudo muy bien ser ficticia - argucia a la que con frecuencia se recurría para evitar emparamientos por deudas $u$ otras causas-; pero vayamos por partes.

${ }^{391}$ Figura señera de los aragoneses vianistas. En 1472 el rey Juan II tuvo que enfrentarse con uno de los bandos más graves surgidos en Aragón, entre Ximeno de Urrea, vizconde de Biota, y Juan de Luna, señor de Villafeliche.

392 Dicho notario, 1483, fol. 19.

393 Dicho notario y año, fol. 28. 
El 14 de abril de 1485, ante el notario y los testigos, Miguel de Matas, como procurador de don Ximeno de Urrea, entró en las casas vendidas por Juce Carillo y tomó posesión de ellas y de todos los bienes que contenían, con los actos posesorios acostumbrados, sin que nadie se opusiera a ello. A continuación, encomendó las casas a Juce, quien reconoció que las tenía por el vizconde y prometió responder de los logueros - que no se especificaron- a éste. Cumplidos todos los trámites, el notario intimó la toma de posesión y la posterior encomienda al justicia, al baile y a los adelantados ${ }^{394}$.

Cuando meses después, concretamente el 2 de septiembre, ante el notario y los testigos, el corredor Esteban Just, por mandamiento del justicia, iba a proceder a apresar a Juce Carillo, éste le presentó una "firma emanada de la cort» del justicia de Aragón, escrita en pergamino y con el sello de su corte. El corredor la recibió «con la honor et reverencia que se pertenece" y pidió una copia para hacer lo que debiese; copia que el notario le entregó signada y que el corredor otorgó haber recibido ${ }^{395}$.

Al no insertar el notario la copia en su protocolo no se puede saber qué se ordenaba en la "firma», ni si con su presentación pudo evitar Juce, momentáneamente, su encarcelamiento. En el caso de que no fuera así, éste sólo estuvo encarcelado dos días, porque el 4 de septiembre, como carnicero, recibió en comanda del pellijero Alonso Pérez y del especiero Bernardo de Santángel, corredores de la sisa de la villa ese año, sesenta sueldos. Respondió de ellos con su persona y bienes, especialmente con un asno de pelo pardo; y reconoció que

«fecha o no fecha discussion de bienes, pueda ser proceydo a capcion de mi persona" ${ }^{396}$.

Es posible, por tanto, que parte de los problemas del carnicero Juce Carillo tuvieran que ver con el impago de sus cargas impositivas o que la mala administración de sus bienes o el uso de procedimientos no del todo legales, que pudieron terminar con un proceso ante

${ }^{394}$ Dicho notario, 1485 , fols. $31 \mathrm{v}-32$.

395 Dicho notario y año, fols. 66v-67.

396 Dicho notario y año, fols. 67v-68. 
la corte del justicia de Aragón, motivaran que su única propiedad cuando recibió esta comanda, fuera, tal vez de hecho, su asno.

$\mathrm{Si}$ algo tuvo Juce Carillo, con toda seguridad, fue un carácter emprendedor. Poco a poco saneó su economía dando dinero en comandas, cada vez con más frecuencia, de tal manera que en los años siguientes volvió a aparecer en la documentación vista como propietario de casas y fincas. Era dueño Juce de nuevo: de un corral, que en 1488 lindaba con las casas de Juce Taboch y de su mujer Mira Nazir ${ }^{397}$; de unas casas, que lindaban en 1491 con las de Abraham Arruet ${ }^{398}$; de un palacio de unas casas de Ricla; de una viña en El Plano - que pudo ser una de las vendidas al vizconde de Biota- ${ }^{399}$; de un campo en Agra, término de Cabañas, y de dos viñas en Candenavas. Parte de estas propiedades se conocen solamente por aparecer al describir los linderos de otros inmuebles, como fue el caso del corral y de las casas, pero de algunas se sabe cuándo las adquirió y cuánto pagó por ellas.

La primera propiedad que adquirió Juce Carillo fue el campo de Agra, que estaba libre de cargas y por el que pagó, el 9 de noviembre de 1488, al labrador Antón de Salas doscientos sueldos ${ }^{400}$. En 1489 compró Juce - hijo de Jaco- a vecinos de Ricla dos viñas, libres de cargas, en Candenavas: una se la vendió el 1 de mayo Ali de Habehut por cien sueldos; la otra, el 29 de septiembre Pedro Castillo y su mujer María de Castro por doscientos ${ }^{401}$. El 11 de enero de 1491, compró Juce — hijo de Jaco— al labrador Martín Millán, de Ricla, un palacio o sala de sus casas del lugar, libre de cargas, que lindaba con ellas y con granero de los herederos de Jaime de Urgel, por setenta sueldos; pero Juce le dio "carta de gracia" de reventa, cuando se los pagara ${ }^{402}$. Y el 17 de julio de 1492, Juce - sastre e hijo de Jaco-, con "voluntat, mandamiento y expresso consentimiento" del justicia Jaime de Matas y del alcalde (sic) de La Hermandad Martín Rasera, comisarios reales de la expulsión, que

397 Dicho notario, 1488, fol. 12.

398 Dicho notario, 1491, fol. 102v.

399 Dicho notario, 1484 , fol. 30v y 1487, fol. 59v.

${ }^{400}$ Dicho notario, 1488 , fol. $81 \mathrm{v}$.

401 Dicho notario, 1489 , fols. $28 \mathrm{v}-29$ y $45 \mathrm{v}-46$.

402 Respondió de él Martín con sus casas (dicho notario, 1491, fols. 2-3). 
estaban presentes, vendió el palacio, libre de cargas, a Martín por el mismo precio que se lo compró ${ }^{403}$.

Mucho antes de que Juce Carillo adquiriera una sala en Ricla, era amigo de los vecinos cristianos del granero con ella colindante. Hacia 1471 se vio a Jaime de Urgel en las cabañuelas de Juce, en La Almunia, jugando con él y comiendo en su interior manjares de carne guisados por judíos ${ }^{404}$. El converso que solía acudir a esta villa cuando se celebraban fiestas, para solazarse y jugar a "tablas" y a «crescas", estuvo también en las cabañuelas de Leon y Acach Almalcani, donde le daban colación de fruta y vino judaico. Como Jaime iba a jugar allí "galloseando", cuando le decían los judíos que, puesto que ganaba, «estrenasse» [regalase], él les daba y, si lo importunaban los judíos que "plegaban» limosna, les entregaba algún dinero ${ }^{405}$.

Dado que el converso Jaime de Urgel tenía casa en La Almunia, se le vio algunos sábados en casa de Juce Carillo comiendo hamin guisado con carne de la judería ${ }^{406}$. El mismo converso reconoció que, hacia 1474, en días de entre semana y en dos o tres ocasiones tomó carne asada, degollada "por rabi judio", y bebió vino "judiego", aunque no recordaba que Juce bendijera la mesa ${ }^{407}$.

Caros pagó Jaime de Urgel sus juegos, diversiones y comidas en La Almunia; pero volvamos a su amigo Juce Carillo.

Además de adquirir las propiedades dichas, a partir de 1486 Juce entregó comandas generalmente de grano, y compró una. El 15

${ }^{403}$ A continuación, Martín y su mujer Sancha de Codos vendieron el palacio a Jaime de Urgel por noventa sueldos, más de lo que les pagó Juce. También en esta venta Jaime otorgó al matrimonio "carta de gracia», consistente en que cuando le pagaran dos cahices de trigo, dos de cebada y cuarenta sueldos, se lo revendería; pero en el caso de que Jaime hiciera algunas reparaciones en el palacio, lo haría con consentimiento de los vendedores y éstos se lo abonarían (dicho notario, 1492, fols. 75v-76v).

404 Z.AAT., leg. del proceso de Jaime de Urgel, sin catalogar, fol. 3: Felipe de Moros, el 2 de abril de 1486; y fol. 18: el acusado Jaime, el 28 de abril de 1490 en Zaragoza.

${ }^{405}$ Dicho leg., fols. 15-15v: Jaime, el 16 de octubre de 1489 en La Aljafería. A Jaime de Urgel me referí también en Relación, IV, pág. 178.

406 Dicho leg., fol. 3: Felipe de Moros, el 2 de abril de 1486; y fol. 15v: Jaime, el 16 de octubre de 1489 en La Aljafería.

407 Dicho leg., fol. 13v: Jaime, el 11 de julio de 1489 en Zaragoza. No creía Jaime que lo comiera en viernes ni sábado ni en la mesa de Juce, pero no estaba seguro, aunque si el dicho Carillo lo dice, "el quiere estar a lo que diraw. 
de noviembre de ese año, dio a Bartolomé Ximeno, de Ricla, tres cahices seis fanegas de trigo y diez fanegas de cebada ${ }^{408}$. El 24 de abril de 1489, Juce - hijo de Jaco- compró a Acach Abenforna los ciento veinte sueldos que Ali de Habehut, también de Ricla, le debía en comanda ${ }^{409}$, y pagó por ella esa misma cantidad ${ }^{410}$. El 1 de mayo Juce compraba a Ali una viña en Candenavas, como se ha visto, pero se comprometió a no exigirle el pago de la comanda, a no ser que en la viña "mala voz salliesse» ${ }^{111}$. El 11 de noviembre Juce - sastre e hijo de Jaco- dio al labrador Lorente del Campo, de Ricla, tres cahices seis fanegas de trigo y diez fanegas de cebada ${ }^{412}$. El 16 del mismo mes dio al labrador Juan Álvarez cinco cahices de trigo ${ }^{413}$. El 19 de mayo de 1490, Juce - sastre e hijo de Jacoentregó al mismo Juan cincuenta sueldos ${ }^{414}$. El 1 de noviembre dio al citado Lorente del Campo cinco cahices tres fanegas de trigo ${ }^{415} ; \mathrm{y}$

${ }^{408}$ Respondió de ellos Bartolomé con sus casas de La Almunia, que lindaban con las de Simuel Albala, con las de la judía Çidiella y con carrera pública (dicho notario, 1486, fol. 108v).

409 Otorgada el 5 de agosto de 1487 en La Almunia, ante el notario Antón de Archant.

${ }^{410}$ Respondió de ellos Acach con sus casas de la judería (L.A.APN., Miguel Contín, 1489 , fols. 28-28v).

411 Dicho notario y año, fols. 29-29v.

412 Respondió de ellos Lorente con un albar sembrado de trigo en Alpartir, otro en La Carrera la Glera y un campo en Canavas, término de Cabañas, sembrados ambos de candeal (dicho notario y año, fols. 56-56v). Precisamente de esta comanda fue testigo instrumental Juce Carillo, hijo de Jehuda. Podría pensarse que este Juce era el que vendió sus bienes al vizconde de Biota, el que estuvo a punto de ser encarcelado, si es que no lo fue, y el carnicero que recibió la comanda de los corredores de la sisa; y que Juce Carillo, el hijo de Jaco, era el sastre que desde 1486 dio comandas y adquirió propiedades inmuebles. Podría pensarse también que las noticias de Juce Carillo anteriores a 1489 , se refieren al hijo de Jehuda, y las posteriores a ese año, al otro Juce que, al incorporarse por su mayoría de edad a la vida económica y social de la villa, como señal de identidad y para evitar la confusión con el otro Juce, se añadiera a su nombre y apellido su oficio de sastre y el nombre de su padre Jaco Carillo. No creo, sin embargo, que haya nada que avale, documentalmente, estas posibilidades, distintas a la opción adoptada por mí. Siguiendo con la comanda entregada por Juce - sastre e hijo de Jaco- a Lorente, la canceló el judío el 1 de noviembre de 1490 (dicho notario, 1489, fol. 56, al margen).

${ }^{413}$ Respondió Juan de ellos con sus casas y una viña en El Romeral (dicho notario y año, fols. 58-58v).

414 Respondió Juan de ellos con una viña en Candenavas (dicho notario, 1490, fols. 35-35v).

415 Respondió de ellos Lorente con un albar en La Carrera de Ricla y un campo bajo Los Ribazos, término de Cabañas (dicho notario y año, fol. 72v). 
al mozo Pascual de Berdejo, también de Ricla, cuatro cahices de trigo, uno de cebada ${ }^{416}$ y cien sueldos, que le devolvería, cincuenta en agosto de 1491 y los otros cincuenta en dicho mes de $1492{ }^{417}$. Y el 6 de noviembre de 1491, el sastre Juce dio al labrador Domingo López cinco cahices de trigo y diez fanegas de cebada ${ }^{418}$.

Las comandas de las que se tiene noticia que Juce entregó desde 1486, año en que asistió a la reunión de la aljama que tuvo lugar el 11 de abril, ponen de manifiesto que su economía era saneada.

El sastre Juce, hijo de Jaco, debió de salir con los demás judíos de la villa, porque el 17 de julio de 1492, vendió la sala de unas casas de Ricla, a su anterior propietario; venta que hizo con el permiso de los dos comisarios reales de la expulsión y ante ellos, como se ha visto.

El único dato que aporta la documentación vista de los años que abarca este estudio, sobre Salamon Carillo, es que sus casas de la judería lindaban con las de Acach Abenforna en $1489{ }^{419}$.

Por lo que se refiere a Semahon Carillo, se sabe que vivió en unas casas de la judería, que lindaban con las de Mosse Abenforna ${ }^{420}$, y que fue dueño de una viña en El Sisallar ${ }^{421}$. No consta en la documentación vista que fuera dueño de otros inmuebles, pero sí que hizo dos entregas en comanda. Una, el 23 de noviembre de 1491, cuando entregó al tejedor Juan González doscientos sesenta sueldos, que juró devolverle en mayo de $1492^{422}$; y otra, el 21 de

${ }^{416}$ Respondió de ellos Pascual con un campo en San Pere y otro en Mateo (dicho notario y año, fols. 72v-73). El 27 de enero de 1494, Jaime de Matas, como procurador del conde de Ribagorza y sustituyendo al caballero mosén Juan Ximeno, la canceló (dicho notario, 1490, fols. 72v-73, al margen).

417 Respondió de ellos Pascual con un campo en "El Colliello», término de Ricla, y con un par de novillas, una de pelo "royo" y otra de pelo "vayo" (dicho notario y año, fols. 73-73v).

${ }^{418}$ Respondió de ellos Domingo con una viña en Candenavas y otra en Los Medianos (dicho notario, 1491, fols. 99-99v).

419 Dicho notario, 1489, fol. 28.

${ }^{420}$ Dicho notario, 1488 , fol. $69 \mathrm{v}$.

${ }^{421}$ Dicho notario, 1492, fol. 117.

${ }^{422}$ Respondió de ellos el tejedor con sus casas y un majuelo en La Cuesta (dicho notario, 1491, fols. 106v-107). El 16 de marzo de 1495, el justicia Jaime de Matas, como procurador del conde de Ribagorza y sustituyendo al caballero Juan Ximeno, canceló esta comanda (dicho notario, 1491, fols. 106v-107, al margen). 
marzo de este mismo año, cuando entregó a los pelaires Jaime Esperandeo y a su hijo Pedro Martínez ciento treinta y ocho sueldos tres dineros ${ }^{423}$.

Hay que admitir como probable, que Semahon Carillo, que fue uno de los asistentes a la reunión de la aljama que tuvo lugar el 11 de abril de 1486, no saliera con los judíos expulsados porque, entre los tres compradores de todos los bienes muebles e inmuebles de Sento Çarfati, se encontraban su mujer Mira, Alazar Ferrer y el propio Semahon Carillo. La venta se hizo el 19 de julio de 1492, como se ha visto, y el precio pagado fueron ochocientos sueldos ${ }^{424}$.

Por lo que respecta a Acach Carillo, se sabe que era hijo de Semahon, porque como tal hizo de testigo instrumental el 14 de octubre de $1491^{425}$.

El 6 de diciembre de ese mismo año, Acach dio en comanda al pelaire Pedro Martínez - quizá el mismo al que luego le prestó su padre- y a su mujer María Casado doscientos ochenta y dos sueldos, que juraron devolverle ese mismo día ${ }^{426}$. Pero no fue así, porque hasta el 21 de marzo de 1492 no la canceló Acach ${ }^{427}$. Esta cancelación no puede aportar dato alguno, que permita conocer si, una vez promulgado el edicto, el propósito de Acach fue irse de la villa con los demás expulsados.

\section{Cohen}

Este apellido lo llevaron en la villa, en los años que abarca este estudio ${ }^{428}$, los siguientes judíos: Abraham, marido de Reyna Gotina, de la que tuvo dos hijos, Cinha y Mosse, que fue tejedor; Aljohar, viuda de Jaco Carillo; Hahim, alias Montañés, marido de Bellida de Sos, hermano de Abraham y tutor de su sobrina Cinha; el tejedor Hahim, menor; Salamon, y el sastre Salamon, menor.

Abraham Cohen se casó con Reyna Gotina, hija de Juce Gotina

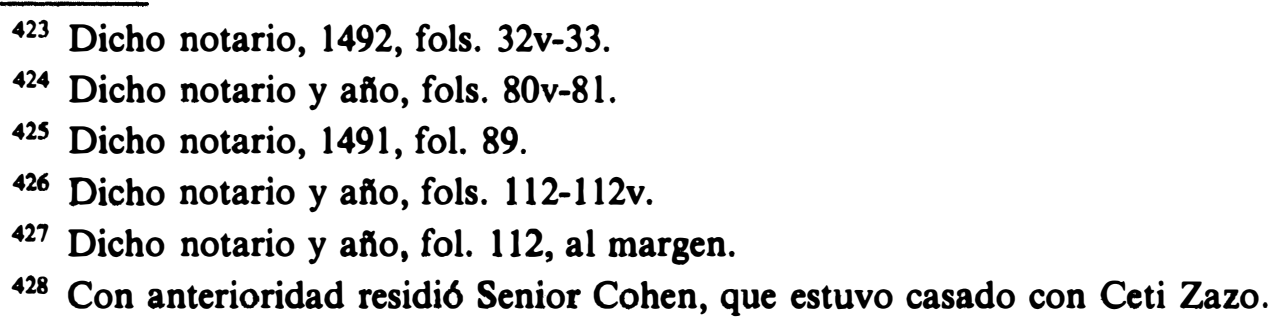


y hermana de Salamon y Vitas Gotina, que vivían en Épila. El 11 de agosto de 1485, los tres hermanos Gotina y Abraham Cohen, como marido de Reyna, comparecieron ante el notario como herederos del difunto Juce Gotina. Manifestaron que defenecían a Juan de Clariana, de Ricla, de una comanda que debía a Juce y le cancelaron cualquier cantidad que a ellos les adeudara. Salamon y Vitas debieron de dar parte del dinero de estos débitos a su hermana Reyna porque, a continuación, Juan reconoció tener en comanda de los dos hermanos Gotina cien sueldos, que les devolvería el día de Todos los Santos de $1486{ }^{429}$.

Abraham y Reyna parece que tuvieron dos hijos: Cinha, que a la muerte de sus padres era menor de edad, y Mosse. No se sabe dónde vivió el matrimonio en la villa, pero sí que fueron dueños de dos majuelos en El Romeral ${ }^{430}$.

Abraham Cohen debió de morir en agosto de 1486, porque el día 20 los adelantados de la aljama nombraron tutor y curador de la persona y bienes de su hija menor Cinha Cohen a su tío carnal Hahim Cohen, alias Montañés. Al no hacerse alusión a la madre de la niña y mujer de Abraham, pienso que cuando éste murió sin hacer testamento, ya estaba viudo de Reyna Gotina.

$\mathrm{Al}$ año justo de su designación como tutor de Cinha, Hahim Cohen, con "voluntat, licencia et expresso consentimiento" de los adelantados ${ }^{431} \mathrm{y}$ como tutor y certificado del derecho de la tutela, vendió al mozo labrador Bernardo de Acha el majuelo de su pupila, sito en El Romeral, que lindaba con la carrera de Alpartir y que estaba libre de cargas. Por él pagó el joven labrador setenta y cinco sueldos, que Hahim otorgó haber recibido; pero se estipuló en la venta que si surgían problemas por el derecho de propiedad del majuelo, el tutor respondería con una viña de su propiedad sita en El Plano ${ }^{432}$.

Por lo que se refiere al tejedor Mosse Cohen, hijo de Abraham y

${ }^{429}$ Respondió de ellos Juan con dos viñas que tenía en La Carrera la Glera (dicho notario, 1485, fols. 55-56). El 4 de mayo de 1487, Salamon y Vitas Gotina la cancelaron (dicho notario, 1485, fol. $55 \mathrm{v}$, al margen).

${ }^{430}$ Dicho notario, 1486, fol. 110 y 1487, fol. 59.

431 Según licencia hecha en acto público ese mismo día.

${ }^{432}$ Dicho notario, 1487, fols. 59-59v. 
de Reyna, sólo aparece nombrado cuando el 1 de agosto de 1491, ante el notario y los testigos, entró en una viña sita en La Cuesta. Mosse manifestó allí que "por algunas causas et titoles en su tiempo et lugar demostraderos", tomaba posesión de ella; cosa que hizo con los actos posesorios acostumbrados y sin contradicción de persona alguna ${ }^{433}$. Sorprendentemente y a continuación, ese mismo día, ante dichos notario y testigos y con títulos que en su momento demostraría, también tomó posesión de la viña Salamon Cohen y tampoco se opuso nadie a que lo hiciera ${ }^{434}$.

Aljohar Cohen, que aparece como viuda de Jaco Carillo en los años que abarca este estudio, vivió en unas casas que, en 1488, lindaban con las de Jaime de Urgel, menor ${ }^{435}$, y en 1492, con las de éste, con las de Mosse Saltiel, con las de la viuda de Miguel de Longares, con las de la viuda de Just del Campo, con las de Antón de Salas ${ }^{466}$ y con el hospital de los judíos ${ }^{437}$. Era dueña Aljohar, además, de una viña en La Carrera la Glera ${ }^{438}$.

Aljohar Cohen entregó en alguna ocasión grano y dinero en préstamos o comandas. En 1485 lo hizo a vecinos cristianos de Ricla: el 9 de marzo Ferrando Cuéllar juró pagarle dos cahices de cebada ${ }^{439}$; y el 14 del mismo mes ella dio a Andrés Martínez noventa sueldos en comanda ${ }^{440}$.

El 2 de agosto de este mismo año, los adelantados de la aljama nombraron a Aljohar Cohen y a Simuel de Leon ${ }^{441}$, de Daroca, tutores y curadores de la persona y bienes de Alazarico y Reynica

${ }^{433}$ Dicho notario, 1491, fols. 67-67v.

434 Dicho notario y año, fol. 67v. A un Mosse Cohen, que vivió en 1444, me referí en Calatorao, II, 182.

${ }^{435}$ Dicho notario, 1488 , fol. $43 \mathrm{v}$.

${ }^{436}$ En los linderos, demasiados para unas casas, debía de estar incluido el corral de las mismas, porque en 1486 el corral de Aljohar lindaba con casas del labrador Antón de Salas (dicho notario, 1486, fol. 36).

437 Dicho notario, 1492, fol. 82.

438 Dicho notario, 1485, fol. 78.

439 Dicho notario y año, fol. $22 \mathrm{v}$.

440 Dicho notario y año, fols. 23-23v. Esta comanda la canceló Aljohar el 30 de mayo de 1492 (dicho notario, 1485, fols. 23-23v, al margen).

441 A él me referí en mi libro Relación, IV, pág. 81, nota 202. 
Alpullat, hijos del difunto Jehuda Alpullat, como se ha visto ${ }^{442}, y$ como tales vendieron bienes de ambos pupilos ${ }^{443}$.

A Aljohar Cohen le tocó vivir los tristes días de la expulsión, posiblemente acompañada por sus nietos, los pupilos Alazarico y Reynica Alpullat. El 9 de julio de 1492, las casas de Aljohar, con todos "los vaxiellos vinarios et olearios», y su viña, fueron vendidos por el justicia Jaime de Matas y por el juez de La Hermandad Martín Rasera, comisarios reales para la expulsión, al prior, frailes y convento del monasterio de Santa María del Carmen, de Zaragoza, como parte de pago de un censal que la aljama de los judíos de La Almunia les debía a éstos ${ }^{444}$.

Sólo me queda señalar respecto a Aljohar Cohen que si era viuda de Jaco Carillo - del que se tiene noticia hasta 1451 y que en 1444 se dice que era sordo- ¿por qué al referirse a ella y a Juce Carillo no se los relaciona? ¿Había contraído Jaco Carillo dos matrimonios o hubo también dos Jaco Carillo? En uno u otro caso, lo que sí está claro es que la madre de los pupilos Alpullat era hija de Aljohar, pues como abuela de los niños aparece ésta.

Ya se ha dicho que Hahim Cohen, alias Montañés, fue designado en 1486 tutor y curador de la pupila Cinha, hija de su hermano Abraham Cohen, y que como tal vendió un majuelo de ésta a un labrador de la villa. Se ha visto también que Hahim asistió a la reunión de la aljama del 3 de mayo de 1483, que actuó como corredor de la misma en 1485 y 1486, y que convocó a los asistentes de la que tuvo lugar el 11 de abril de este último año.

Hahim Cohen estuvo casado con Bellida de Sos. No se sabe si el matrimonio tenía casas en la judería de la villa que fueran de su propiedad, pero sí que eran dueños de una viña ${ }^{445}$ y un albar en $\mathrm{El}$ Plano, y de un majuelo en El Romeral.

El 26 de abril de 1492, días antes de que se hiciera público el edicto de expulsión, Hahim y Bellida vendieron su albar de El Plano, libre de cargas, al pellijero Alonso Pérez por treinta y cinco sueldos, que otorgaron haber recibido. Respondió de ellos el matri-

\footnotetext{
442 A ello me referí más extensamente al hablar de la tutela.

443 A ello me referí más ampliamente al hablar de los Alpullat.

444 Dicho notario, 1492, fols. 82v-83.

445 Con ella había respondido cuando vendió el majuelo de su pupila.
} 
monio, si salía "mala voz», con sus personas y bienes, especialmente con su majuelo de El Romeral ${ }^{446}$.

Ésta es la última noticia del matrimonio que aporta la documentación consultada, pero posiblemente saldrían de la villa con los demás judíos, tal vez acompañados por la pequeña Cinha, a la que nunca se relaciona con su hermano Mosse.

Por lo que se refiere a Hahim Cohen, menor, sólo se sabe que era tejedor y que, el 6 de febrero de 1492, actuó como testigo instrumental en una comanda entregada por Johanan Frances a dos cristianos vecinos de Alpartir, padre e hijo ${ }^{447}$.

El tejedor Salamon Cohen, hijo de Mosse Cohen y de Dona de Cohen, fue uno de los asistentes a la reunión de la aljama del 11 de abril de 1486, donde fue nombrado sobretachador de la pecha, como se ha visto. Salamon Cohen vivió en unas casas de la judería, que lindaban con las de Jaco Albala, con las de Salamon Almalcani y de su mujer Çidiella y con la carrera pública ${ }^{448}$. Era dueño, además, de una viña ${ }^{49}$ y un majuelo en El Ginestar ${ }^{450}$, una viña y dos majuelos en El Romeral ${ }^{451}$ y es posible que de una viña en La Cuesta ${ }^{452}$.

No eran pocos, ni mucho menos, los bienes inmuebles de Salamon Cohen, a cuya adquisición bien pudieron ayudarle algunos préstamos y comandas que entregó. Aun así, éstos no los dio con la frecuencia que cabría esperar, dado el número de propiedades suyas en los términos de la villa. Hay que señalar, sin embargo, que si en los primeros años de la década de los ochenta Salamon entregó comandas y recibió las que le debían - por ejemplo, el 3 de enero de 1483, dio a Calema Ferriz, molinero moro de Villafeliche, ochenta

${ }^{446}$ Dicho notario, 1492 , fols. $56-56 \mathrm{v}$.

447 Dicho notario y año, fol. 10.

448 Dicho notario, 1486, fol. 62v y 1491, fol. 81v. En 1490 las casas de María Just, viuda del labrador Domingo Gómez, lindaban con las de Salamon Cohen, con las de Çidiella y con la carrera (dicho notario, 1490, fols. 63-63v).

${ }^{449}$ Podrían ser dos, pero no aparecen muy claros los linderos.

${ }^{450}$ Dicho notario, 1491, fols. 36 y 81.

${ }^{451}$ Dicho notario, 1486, fol. 105,1487 , fol. 62 y 1489, fols. 58-58v.

${ }^{452}$ Dicho notario, 1491 , fol. $67 \mathrm{v}$. 
sueldos ${ }^{453}$ y el 27 de junio del año siguiente, recibió de Antón de Longares, menor, de Ricla, cien sueldos de los doscientos catorce que le debía en comanda- ${ }^{454}$, las cosas no debieron de irle demasiado bien porque, el 10 de agosto de 1486, fue él quien recibió del escudero Ochona de Ortubia cuatrocientos ochenta y cuatro sueldos, que debería devolverle, la mitad el primer día de Nadal de 1487 y la otra mitad a mediados de la cuaresma de dicho año. Respondió Salamon de esta comanda con sus casas de la judería, con su viña de El Ginestar y con un majuelo de El Romeral ${ }^{455}$. El 10 de enero de 1487, Ochona recibió de Salamon doscientos cuarenta sueldos, parte de la comanda que le debía ${ }^{456}$.

Durante los dos años siguientes, la documentación vista para este trabajo no aporta dato alguno sobre Salamon Cohen, que permita conocer cómo se desarrollaba su vida, aparte de algunos linderos de sus propiedades inmuebles, que se mencionan.

El 25 de marzo de 1490 en Zaragoza, Salamon volvió a recibir en comanda del escribiente zaragozano Miguel de Valtueña cien sueldos, que prometió devolverle el siguiente mes de julio ${ }^{457}$. Y el 31 de agosto de dicho año en Épila, el tejedor Salamon compró a su madre, la viuda Dona de Cohen, todos sus bienes muebles e inmuebles, nombres, derechos, acciones y todo lo que le pertenecía o pudiera pertenecerle. El precio de ellos, mil sueldos, otorgó ella haberlo recibido; y tomó quinyan según ley de judíos en poder de Salamon Amiello ${ }^{458}$.

No había transcurrido un año, concretamente el 1 de febrero de 1491, cuando Salamon dio en comanda al labrador Pedro Moreno dos cahices una fanega de trigo ${ }^{459}$. Y el 1 dé agosto de ese mismo

${ }^{453}$ Respondió de ellos Calema con un asno de pelo pardo (dicho notario, 1483, fols. lv-2). Esta comanda la canceló Salamon el 5 de junio del mismo año (dicho notario y año, fol. $1 \mathrm{v}$, al margen).

${ }^{454}$ Hecha el 13 de octubre de 1483 en Ricla (dicho notario, 1484, fol. $31 \mathrm{v}$ ).

${ }^{455}$ Dicho notario, 1486, fols. 62v-63. La comanda la canceló Ochona el 12 de octubre de 1489 (dicho notario, 1486, fol. 62v, al margen).

${ }^{456}$ Dicho notario, 1487 , fols. $4-4 v$. Véase en la nota anterior la fecha de la cancelación total de la comanda.

457 Z.APN., Miguel de Villanueva, 1490, fol. 154v.

${ }^{458}$ Z.APN., Antón de Abiego, 1490, fol. 80v).

${ }^{459}$ Respondió de ellos el labrador con un majuelo en El Romeral (L.A.APN., Miguel Contín, 1491, fols. 14-14v). 
año, Salamon tomó posesión de una viña en La Cuesta, instantes después de que lo hiciera Mosse Cohen, como se ha visto. Es ésta la última noticia de Salamon Cohen, pues nada más se sabe de la viña, cuya propiedad se disputaban los dos Cohen, ni de los títulos que para pretender su posesión tenían.

No puedo asegurar que Salamon Cohen viviera en los días que precedieron a la expulsión. $\mathrm{Si}$, por un lado, la actuación de un sastre Salamon Cohen, menor, como testigo instrumental el 17 de abril de $1492{ }^{460}$, induce a pensar que había otro Salamon Cohen, mayor, que sería al que me he referido, por otro, resulta extraño que nada se sepa de éste durante ese mismo año. El parentesco que pudo haber entre estos dos Salamon Cohen, y entre ellos y los Cohen antes citados, se ignora.

\section{Çuri}

El único judío con este apellido que residió en la villa, en los años que abarca este estudio, fue Juce. Juce Çuri vivió en unas casas de la judería, que lindaban con las de maestre Jaco Albala y con casas y corral de Miguel Pellicero. Su oficio debió de ser el de curtidor, porque tuvo una tañería en la carrera «del borde, a la puerta Cabanyas", que lindaba con corral de herederos de Pero Serón por dos partes, con casas de Berenguer Garcés y con carrera pública. Juce Çuri fue dueño, además, de una viña en El Ginestar. Parece que Juce no se casó, porque en la villa sólo él llevó el apellido Çuri, lo que induce a pensar también que su familia era oriunda de otro lugar ${ }^{461}$.

No consta cuáles fueron las causas que llevaron a Juce Çuri a desprenderse de parte de sus bienes. El 15 de abril de 1485, Juce vendió un pedazo de su tañería, que estaba libre de cargas, al pellijero cristiano Alonso Pérez por treinta sueldos, de los que respondió con su viña de El Ginestar ${ }^{462}$. Nueve meses después, concretamente el 20 de enero de 1486, Juce vendió sus casas de La Almunia, libres de cargas, al escudero Diego de Herrera, de Épila,

${ }^{460}$ Dicho notario, 1492, fols. 54-54v.

${ }^{461}$ El apellido aparece en judíos de Borja y de Ejea de los Caballeros, entre otros (véase Relación, IV, pág. 113, nota 336).

${ }^{462}$ Dicho notario, 1485 , fols. $32-32 v$. 
por quinientos sueldos. A continuación, éste tomó posesión de ellas con los actos posesorios acostumbrados; luego se las encomendó a Juce, quien reconoció tenerlas «en su nonbre como logatario»; no se especificó por cuánto tiempo ${ }^{463}$.

A partir de la venta de sus casas y hasta 1492, la documentación vista no vuelve a aludir a Juce Çuri, tal vez, porque su situación económica le impedía actuar. Fue en dicho año y después de que los judíos hubieran salido de Aragón, cuando la honradez de Juce Çuri, de Acach Abenforna y de Johanan Frances se puso en entredicho en relación con las propiedades de dos cristianas muy pobres, madre e hija, cuyas casas y corral lindaban con las de Juce.

\section{Chinillo}

El único judío con este apellido que aparece viviendo en la villa, en los años que abarca este estudio, fue maestre Vidal Chinillo, y su residencia, que alternaba con la de Zaragoza, estuvo motivada por la administración de los bienes heredados por su mujer y su cuñada, según parece. Maestre Vidal Chinillo fue hijo del médico maestre Noha Chinillo ${ }^{464}$ y de Duenya Abenardut, que vivieron en Calatayud y Zaragoza, y nieto por línea materna del también médico Juce Abenardut y de Reyna, que residieron en esta última ciudad. Los servicios, buen comportamiento y "honras» de su padre Noha hicieron que su abuela Reyna nombrara a Vidal heredero de todos sus bienes, por partes iguales, con su madre y sus tías Mira y Bonadona ${ }^{465}$.

La profesión de Vidal fue la misma de su padre y abuelo materno, y la mujer con la que contrajo matrimonio, Estruga, era también hija del médico maestre Jaco Albala y nieta de maestre Jaco Albala, mayor, que vivieron en la villa de La Almunia. La boda de Vidal y Estruga, que fue muy celebrada, tuvo lugar en

${ }^{463}$ Dicho notario, 1486, fols. 9v-10.

${ }^{464}$ A él me he referido en varias ocasiones, entre otras, en Relación, III, 277, notas 92 y 93.

${ }^{465}$ Véase mi artículo Últimas voluntades judias: testamentos de Duenya Falaquera, Reyna Abenardut y Davit Rodrich (siglo XV), en "Anuario de Estudios Medievales" 15 (1985), 501-506 (en adelante, Últimas voluntades). 
Zaragoza entre los años 1477-1481 y a ella asistieron algunos conocidos conversos de la ciudad ${ }^{466}$.

Cuando el médico maestre Jaco Albala, hijo, hizo testamento ${ }^{467}$, dejó a sus hijas Estruga y Jamila, aún doncella, herederas universales de todos sus bienes, y como a su muerte la primera estaba casada, fue su marido maestre Vidal Chinillo quien se ocupó de la administración de los bienes que las dos hermanas Albala tenían, al nombrarlo ambas su procurador ${ }^{468}$, aunque pasados unos años, maestre Vidal diera a su mujer un poder general para que actuara en su nombre ${ }^{469}$. Pero la administración de los bienes que maestre Jaco Albala dejó a su muerte, no era fácil. Además de los préstamos y comandas entregados por éste, ya comentados, había otros deudos que se le debían - cuyo conocimiento lo proporciona la documentación de los años posteriores a su fallecimiento-, y que sus hijas se propusieron cobrar como herederas universales de todos sus bienes: comandas entregadas a un concejo y aljama, y a cristianos y moros residentes en diversos lugares, y censos comprados a concejos de sitios cercanos a La Almunia. Pero también había en poder de Estruga y Jamila una serie de péñoras que, una vez efectuados los cobros, tendrían que devolver a los deudores. Fue, según parece, la cuantía de los bienes e intereses de su mujer y cuñada en la villa y lugares próximos, la causa del cambio de residencia de maestre Vidal, que pasó a vivir de Zaragoza, donde lo hacían sus padres, a La Almunia, al menos temporalmente.

Uno de los lugares donde tenían grandes intereses Estruga y Jamila, como herederas de maestre Jaco Albala, era Longares. No está clara la causa por la que, el 4 de junio de 1488 en Zaragoza, maestre Vidal, como procurador de ambas, vendió a su padre maestre Noha mil sueldos censales, que el justicia, jurados, concejo y universidad del lugar debían a las dos hermanas. El precio que maestre Jaco Albala pagó por el censo fue de diecisiete mil quinientos sueldos, diecinueve mil pagó maestre Noha, según se dijo, a su

\footnotetext{
${ }^{466}$ Puede consultarse Relación, II, 272-274.

${ }^{467}$ El 14 de noviembre de 1487, ante el notario Remón López, según alusión que a él se hizo.

468 Según poder hecho el 20 del mismo mes y año, ante el dicho notario de la villa.

469 Otorgado el 7 de octubre de 1491 en Zaragoza, donde el médico vivía entonces (Z.APN., Miguel de Villanueva, 1491, fols. 503v-504).
} 
hijo ${ }^{470}$. Efectuada la compra del censo, maestre Noha nombró procurador suyo a Vidal ${ }^{471}$.

Es posible que la venta del censo a su padre y el poder general que éste dio a Vidal complicara los pagos relativos a dicho censo. El caso fue que, el 17 de febrero del año siguiente en La Almunia, Vidal, en su nombre y como procurador de Estruga y Jamila, dio poder general a pleitos a su padre Noha ${ }^{472}$, y el 18 de noviembre de dicho año en Zaragoza, nombró también procurador suyo, y para que lo sustituyera como procurador de las dos hermanas Albala, a un Vidal Chinillo ${ }^{473}$ que vivía en esta ciudad y era hijo del difunto Jaco Chinillo, de Híjar. Pero cuando se otorgó este último poder, el justicia, jurados, concejo, universidad y algunos residentes en Longares, por una parte $\mathrm{y}$, por otra, maestre Vidal, su mujer y su cuñada, ya habían recurrido al nombramiento de árbitros y amigables componedores para que aclararan algunos pagos, y habían asignado como tales a don Juan López de Alberuela ${ }^{474}$ y a don Francisco de Soria, jurados de Zaragoza, y al escudero de esta ciudad Carlos de Robres, quienes emitieron la correspondiente sentencia. Intimada ésta, y una posterior adición a ella, a las distintas personas que componían las dos partes en litigio, empezaron a hacerse efectivos en Longares los pagos que los árbitros ordenaron.

Cinco días después de que maestre Vidal diera poder a Vidal Chinillo, concretamente el 23 de noviembre de 1489 en Longares, éste recibió del labrador de dicho lugar Aznar de Bádenas ciento cincuenta y un sueldos ocho dineros, de los cuatrocientos cincuenta y cinco que dichos árbitros le habían mandado pagar durante el mes de noviembre, en un plazo de tres años y en tres tandas

${ }^{470}$ Maestre Vidal "prendo quinyan segun ley de judios en poder de Salamon Alazar" (Z.APN., Miguel de Villanueva, 1488, fols. 103-105).

471 El mismo día 4 de junio y tomó quinyan en poder de dicho Salamon Alazar (dicho notario y año, fols. 105-106).

${ }^{472}$ Sin revocar otros procuradores y tomó quinyan en poder de Yento Amato (L.A.APN., Miguel Contín, 1489, fols. 16-17).

${ }^{473}$ A él aludí en mi artículo En torno a una demanda de pago a rabí Acach Arama ante los dayyanim de Calatayud (siglo XV), en "Michael» XI (1989), 124 (en adelante, En torno).

${ }^{474}$ A él y a su relación con el converso Jaime de Montesa me he referido en Relación, IV, 96-100. 
iguales ${ }^{475}$. A continuación, maestre Vidal pagó a Sancho de Espés los doscientos sueldos que los árbitros le mandaron pagar ${ }^{476}$. Al día siguiente compareció el procurador Vidal y dijo al justicia de Longares que los árbitros habían condenado a sus principales a pagar a Martín Mañes, de La Almunia, treinta y cinco sueldos, pero como éste no estaba en el lugar ni tenía procurador para recibir dicha cantidad, se la dejaba en depósito ${ }^{477}$. A continuación y en cumplimiento de la sentencia, maestre Vidal entregó al propio justicia Domingo Ortín los once sueldos que los árbitros le mandaron pagar, a Lorenzo de Mozota setenta y dos, a Lázaro Segura cuarenta y dos cahices de trigo, al corredor Domingo Pérez, mayor, cinco y a Antón de Mozota veinte sueldos ${ }^{478}$.

Dos días después, el 26 de noviembre en Longares y cumpliendo con lo ordenado en la sentencia, maestre Vidal pagó a Domingo Ortín, a su mujer María Gil, a Asensio Gil y a Andrea Gil, mujer de Julián Pérez, hermanos y vecinos del lugar, y herederos y ejecutores del testamento ${ }^{479}$ de María Gil, alias Salvador, viuda de Blas Salvador, cien sueldos. A continuación, el procurador Vidal, en nombre de sus principales, recibió de Sancho López sesenta sueldos; maestre Vidal entregó a éste una taza de plata que pesaba cinco onzas, poco más o menos; pagó a Martín Cabrero tres cahices de trigo y cinco sueldos; y a Aznar de Bádenas, como procurador de Tomás del Rey ${ }^{480}$, le entregó otra taza de plata; y su procurador Vidal recibió de éste cincuenta sueldos ${ }^{481}$.

El mismo 26 de noviembre en dicho lugar y ante el notario y los testigos, compareció el procurador Vidal, en nombre de maestre Vidal, de Estruga y de Jamila Albala. Entró en las casas de Pero Pérez, menor, y le preguntó a su mujer Catalina de Huriana que

${ }^{475} \mathrm{La}$ cantidad recibida correspondía a la primera tanda; y otorgó albarán de haberla recibido (L.A.APN., Miguel Contín, 1489, fols. 58v-59v).

476 Dicho notario y año, fol. 59v.

${ }^{477} \mathrm{El}$ justicia confesó haberla recibido (diçho notario y año, fols. 59v-60).

478 Dicho notario y año, fols. 60-60v.

479 Hecho el 22 de marzo de 1485 en Longares, ante el vicario mosén Domingo Comuel.

${ }^{480}$ Según poder hecho el 25 de noviembre de 1489 en Longares, ante el notario Antón Montañés.

${ }^{481}$ L.A.APN., Miguel Contín, 1489, fols. 63-64v. 
dónde estaba éste, a lo que respondió ella que en Zaragoza, pero que lo estaba esperando. Entonces Vidal, dirigiéndose al justicia Domingo Ortín, le dijo:

— «Senyor justicia, los dichos mis principales ... son tovidos dar et restituyr una taça de plata y una correa de argent"

según la sentencia; pero como no podía demorar la entrega, continuó Vidal, y no había procurador para recibirla y otorgar el correspondiente albarán, se las enseñaba para evitar que luego se las reclamaran, y exigió lo que Pero debía ${ }^{482}$.

Al día siguiente el procurador Vidal recibió del justicia, jurados, oficiales y concejo de Longares cuarenta y nueve cahices de trigo ${ }^{483}$, de los cincuenta y nueve cahices una fanega, que según la sentencia tenían que pagar a maestre Vidal. A continuación ante el notario y los testigos, compareció Vidal, como procurador del médico judío, de su mujer y de su cuñada, en las casas del concejo donde solían reunirse y, dirigiéndose al justicia Domingo Ortín, a Domingo Gil y Bartolomé de Romanas, jurados ese año, y a otras muchas personas que allí estaban, les dijo que, como procurador, comparecía ante ellos para comunicarles que sus principales habían cumplido todo lo ordenado en la sentencia y que como ellos, según ésta, tenían que dar a los dichos sus principales cincuenta y nueve cahices una arroba (sic) de trigo y sólo les dieron cuarenta y nueve, que le entregaran lo que faltaba; si no lo hacían, protestaría contra el pueblo, los singulares y sus personas y bienes, y contra ellos, como oficiales, por no cumplir la sentencia. Sin admitir la protesta, el justicia y los jurados, en nombre del concejo, dijeron que harian lo que debieran, "havido de su sano consejo» "84. El mismo día 27 en La Almunia, maestre Vidal pagó a Martín Mañes los treinta y cinco sueldos que los árbitros le mandaron en la sentencia ${ }^{485}$.

Todavía en el año 1491 y obedeciendo a dicha sentencia arbitral, los vecinos de Longares seguían haciendo pagos a maestre Vidal, quien los recibía personalmente y como procurador de las hermanas

\footnotetext{
${ }^{482}$ Dicho notario y año, fols. $64 \mathrm{v}-65$.

${ }^{483}$ La medida aquí y en todas las demás entregas que siguen, recuérdese que era la de Zaragoza.

${ }^{484}$ Dicho notario y año, fols. 65-66.

485. Dicho notario y año, fols. 66-66v.
} 
Albala, a la vez que hacía entregas de objetos de plata que tenía de su suegro. El 14 de enero le dio Miguel de Mozota cien sueldos y recibió del médico dos tazas de plata ${ }^{486}$; y el 5 de abril fue Martín Cabrero quien le entregó once florines de oro ${ }^{487}$.

Otra localidad cercana a La Almunia donde las hermanas Albala tenían intereses, como herederas del médico maestre Albala, era Alfamén, lugar del que era señora doña Angelina de Luna. Al tratarse de una comanda y no de un censo, como en el caso de Longares, parece que su cobro no originó problemas, aunque concluyera con un nuevo gravamen, como a continuación se verá.

El 25 de noviembre de 1489 en Alfamén, el procurador Vidal, en nombre de maestre Vidal, de Estruga y de Jamila, recibió del alamin, jurados y aljama de moros del lugar noventa y cinco cahices de trigo y novecientos cuarenta sueldos diez dineros y miaja, que debían a maestre Jaco Albala ${ }^{488}$.

Ese mismo día, después de efectuado el pago, la aljama mora de Alfamén se reunió en dos ocasiones. La primera ${ }^{489}$, en el cobertizo de la Plaza, tuvo por objeto nombrar corredor de la aljama a Ali de Moragas, ante la ausencia del corredor Brahem de Arcos ${ }^{40}$. La segunda ${ }^{491}$, en el cobertizo de la carnicería del lugar, fue para que todos los reunidos, de acuerdo y con el permiso de doña Angelina ${ }^{492}$,

${ }^{486}$ Dicho notario, 1491 , fols. $4-4 v$.

487 Dicho notario y año, fols. $36-36 \mathrm{v}$.

${ }^{488}$ Según comanda hecha en el lugar el 4 de noviembre de 1470, ante el notario Miguel Navarro, vecino de La Almunia (L.A.APN., Miguel Contín, 1489, fols. 6161v).

489 Se hizo por orden del alamin y los jurados y asistieron: "Calema el Hacan, alamin, Brahem de Abulcaçim, alias de la Roseta, Cayt de Cayt, jurados, ... Mohoma el Hacan, alfaqui, Mohoma el Haquin, Brahem del Mocho, Brahem d'Omar, Mohoma d'Aborray, Mohoma el Haçan, mayor, Ali Bibax, Azmen de la Pobla, Azmen Gaçet, Ali d'Alcossuenda, Hamet de Hacan, Juce Açan, Juce d'Aborray, Mecot del Aldea, Farax d'Olaziz, Ayca Alaman, Juce d'Aranda, Haye d'Alfarran, Muca la Pobla, Calema Alaman, Muca d'Olaziz, Muca el Hacan, Brahem d'Alcossuenda y Farax el Mocho".

${ }^{490}$ Que «era ydo fuera del lugar et no lo pudian haver pora fazer el acto infrascripto ... Et por quanto era mucho necessario crehar de nuevo corredor" (dicho notario y año, fols. 61v-62).

${ }^{491}$ Se hizo por orden del alamin y los jurados, los convocó el corredor Ali de Moragas y asistieron los mismos moros que a la anterior.

${ }^{492}$ Según licencia dada el 6 de octubre de 1489 en Zaragoza, ante el notario Antón Maurán. Doña Angelina de Luna, señora del lugar de Alfamén, era "tutriz et curadriz" de su hijo don Francisco de Luna y de sus bienes, según constaba por 
reconocieran tener en comanda de maestre Vidal veinticinco cahices de trigo y cuatrocientos cuarenta y siete sueldos ${ }^{379}$, que pagarían así: doscientos veintitrés sueldos seis dineros en el siguiente mes de diciembre, y el resto y el trigo en agosto de 1490. A continuación, dicha aljama reconoció que existía un déficit entre ella y maestre Vidal de veinte sueldos a favor de éste, y se comprometieron a pagarlos el siguiente mes de diciembre ${ }^{380}$. Los primeros doscientos veintitrés sueldos seis dineros los entregaron el alamin, jurados y aljama de Alfamén a maestre Vidal el 11 de enero de 1490, a través de Cayt de Cayt, que era también jurado ese año ${ }^{381}$. A continuación, el vecino Mahoma de Arcos juró pagarle nueve fanegas de trigo ${ }^{322}$; y los doscientos veintitrés sueldos seis dineros restantes los recibió maestre Vidal el 19 de diciembre de ese mismo año, a través de dicho jurado ${ }^{383}$.

Hubo otra serie de comandas entregadas por maestre Jaco, a cuya devolución y cobro tenían derecho las hermanas Albala, como herederas suyas. Su pago lo recibió maestre Vidal, en su nombre y como procurador de ambas, en el transcurso de los años 1489 y 1490. El 21 de enero de 1489, le entregó Mahoma Valtierra y Ali de Habehut, de Ricla, seis cahices de trigo ${ }^{384}$. Y el 4 de febrero recibió del labrador

«tutella dada et asignada» por el jurista micer Domingo de Santa Cruz, lugarteniente del justicia de Aragón mosén Juan de Lanuza, caballero y consejero del rey, otorgada el 31 de julio de 1482 en Zaragoza, ante el notario residente en la ciudad Jaime Malo, escribano de la escribanía de la corte del justicia, por el notario Juan de Fatás, que la regía por éste. Hubo ocasiones, como el 21 de mayo de 1487 en Alfamén y el 29 de agosto de 1490 en Zaragoza, en las que doña Angelina nombró procuradores para que actuaran en su nombre y como tutora y curadora de su hijo y de los bienes de éste (L.A.APN., Miguel Contín, 1487, fols. 32-32v y 1490, fols. 61v-62). Doña Angelina de Luna, señora también de Villafeliche, tuvo problemas durante su tutoría con algunos vasallos suyos moros, que vivían en este lugar; a ellos me referí en Relación, IV, págs. $57-59$, nota 126.

493 Respondió la aljama de las cantidades recibidas con los bienes y rentas de cada uno de sus componentes y de ella misma, hornos, hostales, adulas y otros bienes muebles e inmuebles.

380 Dicho notario, 1489 , fols. 62-63. El 22 de abril de 1491 en Alfamén, maestre Vidal canceló la comanda y otorgó el correspondiente albarán (dicho notario, 1489, fol. 62, al margen).

381 Dicho notario, 1490, fol. 6v.

${ }^{382}$ El plazo de devolución aquí y en todos los demás que siguen, recuérdese que sería el siguiente mes de agosto, si no se indica otra cosa (dicho notario y año, fols. 6v-7).

${ }^{383}$ Dicho notario y año, fols. $74 v-75$.

${ }^{384}$ Que debían, según comanda hecha el 4 de abril de 1486 en La Almunia, ante el notario Antón de Archant, alias Capilla (L.A.APN., Miguel Contín, 1489, fol. 8). 
Pedro de Orihuel ciento dieciséis sueldos ${ }^{499}$, quien juró que le pagaría, además, doscientos cincuenta sueldos: cien en septiembre de ese año y ciento cincuenta en dicho mes del año siguiente ${ }^{500}$. Días después, concretamente el 25 de febrero en Zaragoza, y para cobrar esta cantidad, maestre Vidal nombró procurador suyo ante el notario Miguel de Villanueva a Juce Hayat, judío de Calatayud, quien el 1 de octubre cobraba del labrador los primeros cien sueldos ${ }^{501}$. El 11 de enero de 1490, maestre Vidal recibió de Juan Marco y de su mujer Pascuala Fuset doscientos veinticinco sueldos ${ }^{502}$. El 18 de enero en el lugar de Pueyo, cobraba de los jurados, oficiales, concejo y universidad del lugar treinta y cinco cahices de trigo ${ }^{503}$. A continuación, maestre Vidal les vendió los veinticinco sueldos censales, anuales y perpetuos, que ellos habían vendido a su suegro ${ }^{504}$, con todas las pensiones "corridas y debidas", por doscientos ochenta sueldos ${ }^{505}$. Luego maestre Vidal recibió de Bartolomé Sediles y de Gil de Almelda ciento catorce sueldos y cinco cahices de trigo ${ }^{506}$. Ese mismo día se reunió el concejo de Pueyo en el "portegado" de la iglesia, llamados por el corredor. Allí, todos de acuerdo, visto que necesitaban alguna cantidad en dinero, hicieron poner venales veintisiete sueldos y medio anuales, censales y perpetuos, y como quien más precio les ofreció fue maestre Vidal, se los vendieron a él, pero con "gracia" de poderlos volver a comprar por doscientos setenta y cinco sueldos ${ }^{507}$. Curiosamente, el 6 de abril de 1489,

499 Que debía a maestre Jaco, según comanda hecha el 7 de marzo de 1474, ante el notario Miguel Navarro.

500 L.A.APN., Miguel Contín, 1489, fols. 11-11v. El 13 de marzo de 1491, maestre Vidal canceló este pago (dicho notario, 1489, fol. $11 \mathrm{v}$, al margen).

${ }^{301}$ Dicho notario y año, fols. 46-46v.

${ }^{502}$ De los trescientos veinticinco que debían a maestre Jaco, según comanda hecha el 31 de mayo de 1487 en La Almunia, ante el notario Miguel Contín (dicho notario, 1490 , fols. $7 v-8$ ).

${ }^{503}$ Que debían a Jaco Albala, según comanda hecha el 7 de febrero de 1487 en Pueyo, ante el notario Antón de Archant.

sos $\mathrm{Y}$ que tenían que pagar el 1 de febrero, según venta censal hecha el 22 de abril de 1459 en Pueyo, ante el notario Juan de Cuéllar, que vivía en La Almunia.

s0s Respondió con sus bienes y los de las hermanas Albala.

s06 Que debían a maestre Jaco, según comanda hecha el 1 de febrero de 1474 en La Almunia, ante el notario Pero López.

507 Tenían que pagarlos cada año en agosto, a partir de dicho mes de 1490; y de la cantidad recibida respondieron con todos sus bienes, casas, campos y ganados (L.A.APN., Miguel Contín, 1490, fols. 10-13). 
maestre Vidal ya había recibido, solamente en su nombre, de los jurados y concejo del lugar de Pueyo, a través de los vecinos Bartolomé Sediles y Antón Fraile, doscientos setenta y cinco sueldos, de los quinientos cincuenta que le tenían que pagar ${ }^{508}$. La verdad es que no sólo durante treinta años los jurados, oficiales, concejo y universidad de Pueyo no habían podido librarse del gravamen del censo, sino que, en 1490, la cantidad que debían de entregar al año se había incrementado en dos sueldos y medio.

Si el cobro de algunas de las comandas que maestre Jaco había entregado no ofreció problemas a su yerno, no ocurrió así con las cantidades debidas por Juan Pascual y su mujer María de Leu, vecinos de Alpartir ${ }^{509}$. El 15 de marzo de 1490 en dicho lugar y ante Juan de Orihuela - lugarteniente del alcalde de Alpartir Jaime Ponte, que lo era además de La Almunia y de Cabañas-, in judicio pro tribunali sedente, comparecieron maestre Vidal por una parte $\mathrm{y}$, por otra María, porque su marido había muerto, para que resolviera el pleito que entre ambos había por dichas cantidades. El lugarteniente, oídas las partes, condenó a María a pagar doscientos treinta sueldos a maestre Vidal, ciento veinte en el siguiente mes de mayo y ciento diez en dicho mes de 1491, y a éste a darle, cuando recibiera las cantidades, carta de pago en su nombre y en el de las hermanas Albala ${ }^{\text {s10. }}$.

Todo lo dicho hasta aquí sobre maestre Vidal Chinillo en el plano económico, está relacionado con los bienes de su mujer y de su cuñada, pero el médico tenía fortuna propia, aunque se viera incrementada por los bienes aportados por Estruga al matrimonio y las cuantías que recibió como heredera de su padre maestre Jaco Albala, junto con su hermana. A la fortuna de maestre Vidal y al uso que hizo de ella voy a referirme a continuación.

El 9 de julio de 1490 en Zaragoza, el médico maestre Vidal, que se encontraba en dicha ciudad, nombró procurador suyo al ya citado mercader Vidal Chinillo, entre otras cosas para que cobrara,

508 Según «albaran de mano" de Juan de Almenda y «firmado de mano» de dicho Bartolomé; maestre Vidal les entregó el correspondiente albarán de la cantidad recibida (dicho notario, 1489 , fols. $22-22 v$ ).

${ }^{509}$ A maestre Jaco, según comandas hechas el 10 de febrero y el 13 de noviembre de 1478, ante el notario Pero López.

510 L.A.APN., Miguel Contín, 1490, fols. 31-32. 
en su nombre, los mil cuatrocientos sueldos que tres cristianos zaragozanos le debían desde $1485^{\mathrm{s}}{ }^{\prime \prime}$.

Por lo que se refiere a las comandas que únicamente en su nombre entregó maestre Vidal a cristianos de La Almunia, a moros de Calatorao, Alfamén, Lucena y Morata, y a cristianos y moros de Ricla, fueron siempre en trigo o en sueldos y, parte de ellas, cabe en lo posible que se hicieran con o en base a las cantidades recibidas de los deudores de su suegro:

El 28 de octubre de 1488, maestre Vidal dio a Berenguer Garcés, a su mujer Violante de Casanova y a su hijo Miguel cinco cahices de trigo ${ }^{512}$.

El 10 de febrero de 1489, entregó a Mahoma don Junez, de Calatorao, diez fanegas ${ }^{513}$; y el 17 de febrero, a Ali el Navarro, del mismo lugar, dos fanegas ${ }^{514}$.

El 22 de enero de 1490, dio de nuevo a Berenguer Garcés de Gaonas, a su hijo Miguel y a Domingo Calatayud nueve cahices de trigo ${ }^{115}$; el 14 de febrero, a Fernando la Vega, de Ricla, cinco cahices ${ }^{516}$; el 5 de marzo, después de haberse reunido el alamin, jurados, oficiales y aljama de moros de Calatorao ${ }^{517}$, llamados por el corredor público Antón de Cifuentes, maestre Vidal les entregó, estando todos de acuerdo, setecientos sesenta sueldos y dieciocho

${ }^{511}$ Z.APN., Juan de Altarriba, 1490, fol. 188v.

512 Respondieron de ellos el matrimonio y su hijo con un majuelo en El Romeral y otro en El Pozuelo (L.A.APN., Miguel Contín, 1488, fols. 74-74v). El 22 de enero de 1490, maestre Vidal la canceló (dicho notario, 1488, fol. 74, al margen).

513 Respondió de ellas Mahoma con un campo en El Manantial, término de dicho lugar (dicho notario, 1489, fols. 11v-12).

514 Respondió de ellas Ali con un campo en El Campo del Rey, término de Calatorao (dicho notario y año, fol. 15v).

s15 Respondió de ellos Berenguer con un majuelo en El Romeral y otro en El Pozuelo (dicho notario, 1490, fols. 14v-15).

516 Respondió de ellos Fernando con sus casas del lugar, con un campo en Longares y con un par de mulos, uno cárdeno y otro castaño (dicho notario y año, fols. 22-22v).

\$17 La reunión tuvo lugar a la puerta de la mezquita y a ella asistieron: "Mohoma d'Alcayne, alfaqui, Farax d'Aranda, alamin, Calema Llavar et Mohoma d'Ayça", jurados ese año, «Farax el Toledano, Mohoma el Toledano, Muca Naval, Brahem d'Atovir, Brahem el Cocho, Ali d'Ovequar, Brahem el Carnicero, Junez d'Atovir, Avdalla el Marranchano, Ali d'Aranda, Mohoma el Morellano, Mohoma don Junez, Ali el Toledano, Ali el Guaxqui, Brahem d'Arquos, Mohoma d'Aljoma, Ali el d'Ayça et Mohoma el Viello". 
cahices de trigo ${ }^{518}$; el día 7 Haye el Mocho, moro de Alfamén, juró pagarle dos cahices tres fanegas ${ }^{519}$; el 19 entregó a Brahem de Farach, a Ali de Ali y a Juce Culeyma, moros de Ricla, siete cahices y medio ${ }^{520}$; el mismo día, a María García, viuda de Juan Catalán, y a su yerno, el labrador Domingo Tena, tres cahices seis fanegas ${ }^{221}$; el 22, a Farax de Aranda, alamin de Calatorao, dos cahices y medio ${ }^{522}$; el 1 de junio, a Ali el Gomero y a Mahoma de Cayt, menor, del mismo lugar, tres cahices seis fanegas ${ }^{523}$; y el 31 de octubre, al labrador Pedro Tejedor, mayor, ciento dieciséis sueldos ${ }^{524}$.

El 14 de enero de 1491, maestre Vidal entregó a Mahoma el Toledano y a Farax el Toledano, mayor, de Calatorao, siete cahices una fanega ${ }^{525}$ y cuatro cahices seis fanegas de trigo ${ }^{526}$, respectivamente; el 21 de dicho mes en este lugar, al alamin Farax de Aranda, a Brahem de Atovir y a Brahem el Luengo, moros del lugar, siete cahices siete fanegas ${ }^{527}$, a Ali de Ovequar cuatro cahices ${ }^{528}$, y a Ali

${ }^{518}$ Respondieron de ellos con sus personas y bienes, y los de la aljama y sus rentas, hornos, pechas y heredades (dicho notario y año, fols. $27 \mathrm{v}-28 \mathrm{v}$ ).

519 Dicho notario y año, fol. 30.

${ }^{520}$ Respondió de ellos Brahem con un olivar en Castallos, término del lugar, y Ali con un campo en el mismo término (dicho notario y año, fols. 33-34). A continuación, Brahem vendió al labrador Juan de Álvarez, vecino de La Almunia, una viña en Candenavas. El 22 de noviembre de 1491, Estruga, como procuradora de su marido -según poder hecho el 7 de octubre de 1491 en Zaragoza, ante el notario Miguel de Villanueva-, canceló la comanda (L.A.APN., Miguel Contín, 1490, fol. 33v, al margen).

${ }^{521}$ Respondió de ellos María con una viña en Candenavas y Domingo con otra en el mismo término (dicho notario y año, fols. 34v-35).

522 Respondió de ellos Farax con un majuelo en El Campo del Rey, término del lugar (dicho notario y año, fols. 35v-36).

${ }^{523}$ Respondió de ellos Mahoma con un campo en Las Viñas, término del lugar (dicho notario y año, fol. 47v: testigo con un cristiano y un moro, rabi Abraham Zecrit, que vivía en La Almunia).

524 Que juró devolverle en el plazo de un año. Respondió de ellos Pedro con una viña en El Pozuelo (dicho notario y año, fols. 71v-72). El 22 de septiembre de 1493, Jaime de Matas, como procurador del señor conde de Ribagorza y sustituyendo al caballero mosén Juan Ximeno, porque el conde don Juan tenía derecho a la comanda "por el recesso" de maestre Vidal, su vasallo, la canceló (dicho notario, 1490, fols. $71 v-72$, al margen).

${ }^{525}$ Respondió de ellos Mahoma con un campo en La Cabaña y otro, llamado Calderón, en El Campo del Rey, términos del lugar (dicho notario, 1491, fols. 3-3v).

${ }^{526}$ Respondió de ellos Farax con un campo en El Cal de las Viñas y otro en El Brazal del Aspro, términos del lugar (dicho notario y año, fols. $3 v-4$ ).

${ }^{527}$ Respondió de ellos Brahem el Luengo con sus casas del lugar (dicho notario y año, fols. 7-7v). 7v-8).

528 Respondió de ellos Ali con un huerto en El Menajal (dicho notario y año, fols. 
de Anzeyt, alamin de Lucena, y a Juce de Ceni, también de Calatorao, cuatro cahices seis fanegas ${ }^{529}$; el 4 de febrero en este mismo lugar, entregó a la aljama mora que se encontraba reunida en el cobertizo de la Plaza ${ }^{530}$, llamada por el corredor público Ali de Gualit, cuarenta y tres cahices dos fanegas ${ }^{531}$ y recibió de ella los dieciocho cahices de trigo que le debía del año anterior ${ }^{532}$; el 17 de febrero, a Ali de Ayça, del mismo lugar, cinco cahices y medio ${ }^{533}$; el 21 de marzo, a Juan Domingo, mayor, labrador de Ricla, siete cahices seis fanegas ${ }^{534}$; el 2 de mayo, a Mahoma Valtierra, moro de este lugar, dos cahices y medio ${ }^{335}$; el día 13 , al labrador Jaime García dos cahices y medio ${ }^{536}$; el día 20, a María Just, viuda de Domingo Gómez, y a su hijo, el mozo Antón Gómez, diez cahices ${ }^{537}$; y el 17 de agosto, a Mahoma el Izquierdo, menor, de Morata, cincuenta sueldos y medio cahiz de trigo ${ }^{538}$.

El prestigio y la estima en que tuvieron a maestre Vidal algunos judíos tuvo que ser grande, al igual que lo fue el de su padre

${ }^{529}$ Respondió de ellos Ali con una viña en «Teriuel» y Juce con otra en El Campo del Rey, términos de Calatorao (dicho notario y año, fols. 8-8v).

530 Estaban "Farax de Aranda, alamin, Mohoma el Viexo et Brahem de Arquos", jurados ese año, "Mohoma d'Alcayne, alfaqui, Farax el Toledano, Brahem d'Atovir, Muca Naval, Calema Llavar, Brahem el Carnicero, Mohoma el Toledano, Avdalla el Marranchano, Mohoma el Morisco, Mohoma d'Aljoma, Brahem del Exerich, Mohoma Benjunez, Ali Hoceu, Ali d'Ovecar, Ali el Toledano, Ali el Guaxqui et Ali d'Ayca".

${ }^{531}$ Respondieron con sus personas y bienes, y los de la aljama y sus rentas.

532 Según comanda hecha el 5 de marzo de 1490 en Calatorao, ante el notario Miguel Contín, en la que también reconocieron deberle setecientos sesenta sueldos, como se ha visto (dicho notario, 1491, fols. 16v-17).

${ }^{533}$ Respondió de ellos Ali con sus casas en el lugar y una viña en El Campo del Rey (dicho notario y año, fols. 22v-23).

534 Respondió de ellos Juan con un campo en "Arquas", término de ese lugar (dicho notario y año, fols. 33-33v).

535 Respondió de ellos Mahoma con un campo en Castallos, término de Ricla (dicho notario y año, fols. 52-52v). El 24 de marzo de 1496, Jaime de Matas, como procurador del conde de Ribagorza y sustituyendo al caballero mosén Juan Ximeno, canceló esta comanda (dicho notario, 1491, fol. 52, al margen).

${ }^{536}$ Respondió de ellos Jaime con sus casas en «barrio Verde" (dicho notario y año, fol. 55).

537 Respondió de ellos María con un majuelo en La Cuesta y otro en Candenavas (dicho notario y año, fols. 56v-57).

538 Respondió de ellos Mahoma con un huerto en El Barranco, término de Chodes (dicho notario y año, fol. 74). El 29 de enero de 1497, Jaime de Matas, como procurador de don Juan de Aragón, conde de Ribagorza, y sustituyendo al caballero mosén Juan Ximeno, canceló esta comanda (dicho notario, 1491, fol. 74, al margen). 
maestre Noha, porque en él depositaron su confianza nombrándole procurador, árbitro para dirimir pleitos e, incluso, tutor y curador.

El 17 de enero de 1490 en La Almunia, Salamon Catorce, de Calatayud, en su nombre y por el derecho que tenía en los bienes de su difunto padre Mosse Catorce ${ }^{339}$, sin revocar otros procuradores, nombró a maestre Vidal su procurador general para pleitos ${ }^{540}$. El 11 de febrero y el 6 de diciembre de ese mismo año en Zaragoza, maestre Vidal fue nombrado árbitro y amigable componedor, junto con el notario zaragozano Juan de Anchias y con Johanan Frances, en el pleito que mantenía su padre maestre Noha y su tía Bonadona, viuda de Mosse Paçagon, de Calatayud, con el hijo de éste, Calema Paçagon ${ }^{541}$. Y el 18 de noviembre también de ese año, cuando el sastre Acach Axech ${ }^{542}$ hizo testamento en Zaragoza, nombró a maestre Vidal tutor y curador de las personas y bienes de sus hijos Jucef, Jona, Bonjuha y Graciana, junto con Acach Abnadayan, con su cuñado Simuel Gallur y con su mujer Mira Gallur ${ }^{543}$, para que actuaran como tales «segund fuero, etc., e ley e pratiqua de judios" ${ }^{544}$.

Maestre Vidal fue también procurador del mercader valenciano Leonardo Roiz, sustituyendo a Jehuda Albala que de La Almunia había pasado a vivir a Belchite ${ }^{545}$. El 13 de marzo de 1491, maestre Vidal, como procurador de Leonardo, vendió al labrador Domingo Fuset los doce sueldos censales del treudo perpetuo que debía a su principal ${ }^{446}$, con las pensiones "corridas y devidas" y con la suerte principal, por ciento veinticinco sueldos de precio ${ }^{547}$; el 5 de abril vendió al labrador Sancho Aznárez los doce sueldos censales y

539 Según la venta de ellos que le hizo el 28 de febrero de 1477 en Calatayud, ante el notario Leonardo de Santa Fe. A Salamon me referí en Relación, III, 290-291, nota 144.

540 L.A.APN., Miguel Contín, 1490, fols. 9-10.

541 A ello me referí en Últimas voluntades, 500, nota 13.

${ }^{542}$ Hermano de Regina y de Bonjuha Axech, que después de su conversión se llamó Antonino.

${ }^{543}$ Mientras no se volviera a casar; vivían los tres en dicha ciudad.

544 Z.APN., Juan de Altarriba, 1490, fols. 295v-296.

545 Véanse notas 299 y 300 de Jehuda Albala.

$546 \mathrm{Y}$ que tenía que pagar el 3 de noviembre, según venta censal hecha el 3 de dicho mes de 1477, ante el notario Miguel Contín.

547 Dicho notario, 1491, fols. 28-29. 
perpetuos que debía a Leonardo ${ }^{548}$, con las mismas pensiones y suerte, pero por ciento veinte sueldos ${ }^{549}$; el 4 de abril de 1492, vendió a Remón de Urgel los cincuenta sueldos censales y perpetuos que debía al mercader valenciano ${ }^{550}$, con las dichas pensiones y suerte, por quinientos sueldos de precio ${ }^{551}$; y el 27 de junio de este mismo año en Zaragoza, maestre Vidal, como tal procurador, vendió al escudero bilbilitano Serrano Muñoz los cien sueldos censales, que el notario Juan Navarro y su mujer Urraca Pellicero debían de pagar el 20 de enero a Leonardo ${ }^{552}$, con las pensiones y prorratas "corridas et devidas" y con la propiedad de aquellos, por mil seiscientos sueldos ${ }^{553}$.

En los primeros meses de 1492, último período que pasaron maestre Vidal y su mujer en La Almunia, aún recibió el matrimonio pagos debidos a maestre Jaco Albala, algunos después de que se hubiera llevado a cabo un juicio para lograr su cobro; para recibirlos necesitó Estruga un poder de su marido.

El 20 de marzo de dicho año, Estruga, en su nombre y como procuradora de maestre Vidal ${ }^{554}$, recibió del justicia, jurados, concejo, universidad y aljama de Ricla, a través del jurado Antón de Longares, menor, sesenta y un sueldos cuatro dineros, de las "despenssas ... que [Vidal] fizo en sentenciar" una carta de comanda en la que estaban obligados a Jaco Albala ${ }^{5 s 5}$.

El 4 de abril maestre Vidal recibió de Remón de Urgel y de su mujer Jordana Rasera doscientos sueldos, de los ochocientos que "en acto publico de condempnacion" hecho ante el justicia Jaime de Matas ${ }^{556}$, tenían obligación de pagarle ${ }^{557}$.

${ }^{548}$ Y que tenía que pagar el 27 de enero, según venta censal hecha el 27 de dicho mes de 1482, ante el notario Antón de Archant.

549 L.A.APN., Miguel Contín, 1491, fols. 36v-37v.

$550 \mathrm{Y}$ que tenía que pagar el 25 de septiembre de cada año, según venta [la fecha en blanco].

551 Dicho notario, 1492, fols. 53-54.

552 Según venta censal hecha el 20 de enero de 1463 en La Almunia, ante el notario Juan Navarro, con muchas y diversas cláusulas y obligaciones; censo por el que Leonardo pagó mil sueldos.

553 Z.APN., Miguel de Villanueva, 1492, fols. 337-337v.

554 Según poder hecho el 7 de octubre de 1491 en Zaragoza, ante el notario Miguel de Villanueva.

sss L.A.APN., Miguel Contín, 1492, fols. 31-31v.

${ }^{556} \mathrm{La}$ fecha en blanco.

557 Como primera tanda, el día de Santa María de Agosto de 1491 (dicho notario, 1492, fol. 53). 
Un día antes en el lugar de Tosos, maestre Vidal, como procurador de las dos hermanas y herederas Albala, recibió de los jurados, concejo y universidad del lugar los cincuenta y un cahices de trigo que debían a su suegro ${ }^{558}$. Luego, convocado "a son de campana" el concejo y llamado por el corredor Antón Férriz, se reunió en la Plaza para recibir en comanda de maestre Vidal, esta vez ochenta y cuatro cahices seis fanegas de trigo ${ }^{559}$.

El 6 de julio, preparando su marcha para abandonar Aragón, maestre Vidal y su madre Duenya Abenardut, con derecho a todos los bienes de su padre y marido maestre Noha, vendieron a Jerónimo Roiz, escudero de Borja, los cien cahices de trigo que a aquél debía en comanda Juan Tomás ${ }^{560}$.

El día 15 maestre Vidal nombró procuradores suyos a su hermano Jehuda Chinillo y a su cuñada Jamila Albala ${ }^{561}$. Haciendo uso de este poder, el día 19 de julio, Jehuda vendió a don Juan de Aragón, conde de Ribagorza, los ochenta y cuatro cahices seis fanegas de trigo, que a su hermano debía el concejo de Tosos, por mil trescientos cincuenta y seis sueldos de precio ${ }^{562}$.

El día 25 volvió a comparecer maestre Vidal para otorgar otro instrumento público ante el notario Miguel de Villanueva, pero no llegó a redactarse.

El médico maestre Vidal, su madre Duenya Abenardut, su mujer Estruga, su hermano Jehuda, su cuñada Jamila y sus hijos, si los tenía, saldrían de La Almunia o de Zaragoza con los demás judíos.

\footnotetext{
558 Según comanda hecha el 25 de noviembre de 1485 en Tosos, ante el notario Alfonso de Torija, residente en Épila.

559 Z.APN., Miguel de Villanueva, 1492, fols. 218-219v.

${ }^{560}$ Dicho notario y año, fols. 367v-368; este instrumento no termina.

$561 \mathrm{Y}$ tomó quinyan en poder de Simuel Cides, alias Parexo (dicho notario y año, fol. 383).

${ }^{562}$ La venta se hizo en La Almunia, «con voluntat, decreto y actoridat de Jayme de Matas e Martin Rasera, comissarios de los bienes de los judios de la dicha villa ... y expulsion de aquellos». El 25 de octubre de dicho año en Zaragoza, Lorenzo de la Caballería, como procurador del conde don Juan - según poder hecho el anterior día 11 en dicha ciudad, ante el notario Miguel de Villanueva-, vendió a Juan Fernández de Heredia, señor de los lugares de Botorrita y Tosos, el trigo recientemente comprado que debía el concejo de este último lugar, por mil trescientos ochenta y seis sueldos (Z.APN., Miguel de Villanueva, 1492, fols. 586-586v).
} 
Eli

Son tres los únicos judíos con este apellido que aparecen como residentes en la villa ${ }^{563}$, en los años que abarca este estudio: rabí Abraham, el sastre Abraham y rabí Mosse, notario, del que nada se sabe.

De rabí Abraham Eli sólo consta que actuó como testigo instrumental, el 3 de octubre de 1485, en una comanda que recibió Simuel Pardo del escudero Luis Navarro ${ }^{564}$.

Por lo que se refiere al otro judío, llamado también Abraham Eli, el 12 de enero de 1484 en Calatayud, recibió en comanda, junto con Simuel Pardo, con Yunez Mehel y con Haya Mehel, del mercader de dicha ciudad Juan Calderón noventa y dos sueldos. Los cuatro judíos de la villa respondieron de la cantidad recibida con sus bienes, pero los de Abraham no se especificaron ${ }^{565}$.

Cuatro años después, concretamente el 13 de diciembre de 1488, el sastre Abraham Eli compró unas casas a Bartolomé Ximeno y a su mujer María de Almudévar ${ }^{566}$. Por ellas, que estaban libres de cargas y lindaban con las de Simuel Samarel, con las de Simuel Albala y con carrera pública, pagó Abraham doscientos treinta sueldos ${ }^{567}$.

Pese a haber adquirido unas casas en la villa y haber sido uno de los asistentes a la reunión de la aljama que tuvo lugar el 11 de abril de 1486, la documentación no aporta más noticias del sastre Abraham Eli, y sí lo hace en relación a un Abraham Eli, residente en Zaragoza, que acostumbró dar dinero en comandas a moros de Calatorao ${ }^{568}$.

${ }^{563}$ Habían residido en La Almunia varios zapateros con este apellido: Hahim Eli, que estuvo casado con Soli Stallo, Juce Eli y Salamon Eli; éste cambió su residencia a Arándiga y fue padre de Caçon Eli. El apellido aparece también en judíos de Épila y Zaragoza, entre otros.

${ }^{564}$ L.A.APN., Miguel Contín, 1485, fol. 78v. En 1453 un rabí Eli había actuado, también, como testigo instrumental en La Almunia.

${ }^{565}$ C.APN., Juan Remón, 1492, fols. 27-27v.

566 Respondió el matrimonio, en caso de "mala voz», con una viña en Candenavas, otra en La Carrera la Glera y un albar en El Ginestar.

${ }^{567}$ L.A.APN., Miguel Contín, 1489, fol. Iv.

${ }^{568}$ Dicho notario y año, fols. $17 \mathrm{v}, 18 \mathrm{v}, 24 \mathrm{v}$ y 25. 
Far

En los años que abarca este estudio, sólo aparecen mencionados dos judíos de la villa con este apellido. La primera alusión hace referencia a los herederos de un Salamon Far, en relación con unas casas de su propiedad, situadas en la Plaza y que lindaban con las de Juce Frances ${ }^{569}$. A los mismos linderos de dichas casas, propiedad en 1492 de un judío llamado también Salamon Far, se alude el 25 de abril de dicho año, cuando el caballero mosén Juan Ximeno, baile de los judíos de la villa, como procurador del señor conde de Ribagorza, tomó posesión de las casas del citado Juce Frances ${ }^{570}$.

\section{Ferrer}

El único judío con este apellido ${ }^{571}$, documentado en los años que abarca este estudio, es Alazar Ferrer. Para referirme a él, a su familia y a su infancia hay que aludir a hechos que sucedieron años antes. Sus padres, Alazar Ferrer y Azibuena, vivieron en unas casas de la villa, que lindaban en 1444, con las de Pero Compañón, mayor ${ }^{572}$, y con las del labrador Alfonso de la Sagrada ${ }^{573}$. Alazar y Azibuena tuvieron tres hijos, Solliqua, Estruguiqua y Alazariquo.

Alazar Ferrer debió de ser un hombre caritativo: sintiendo lástima de un judío, llamado Jaco, le prestó una litera - manta o cobertor«en que durmiesse». La insolvencia de Jaco motivó el embargo de sus bienes muebles y, enterado Alazar, quiso recuperar lo que le pertenecía. El 17 de febrero de 1444, en presencia del notario y los testigos, compareció ante don Miguel de Ainsa, lugarteniente del sobrejuntero de la junta de Tarazona, y le dijo:

- "Vos assi como lugarteniente de sobrejuntero, haveys fecho una exsecucion a Jaquo en siertos bienes mobles, en los quales y haveys presso una litera mia blanqua con listas morenas la qual es esta que teneys alli - la qual el dito Alazar fue y toquo que estava alli en un banquo del almodi de la plaza-, porque vos suplico que, como yo

569 Dicho notario, 1486, fol. 32v.

570 Dicho notario, 1492, fol. 55v.

${ }^{371}$ En Teruel vivieron también judíos apellidados Ferrer.

${ }^{572}$ Que, a su vez, lo hacian con un callizo por donde tenían su entrada y salida (L.A.APN., Pascual Contín, 1444, fol. 15v).

${ }^{573}$ Que, a su vez, lindaban con las de Salamon Bitalis y con carrera pública (dicho notario y año, fol. 51v). 
no deva res a ninguno par que mis bienes se devan exsecutar por otri, que vos requiero e suplico que vos me deys mi litera; en otra manera favlando con vuestro honor que protesto contra vuestra persona e vuestros bienes".

Luego Alazar requirió al notario para que levantara acta. El lugarteniente, sin consentir en las protestas, manifestó que si se levantaba acta, se le diera la copia, y que ni se «borrasse la carta publica» ni corriese el tiempo hasta que él tuviera la copia. Alazar volvió a insistir para que «je le dasse» la litera que había prestado a Jaco para dormir. Finalmente, el lugarteniente requirió al notario para que levantara acta ${ }^{574}$.

Habían pasado sólo unos meses de esta comparecencia de Alazar para pedir que se le entregara su litera blanca con listas morenas, cuando le sobrevino la muerte sin haber hecho testamento y dejando a su mujer esperando un hijo.

El 13 de julio de dicho año, el converso Martín de la Plana, menor, y su hermana Azibuena Ferrer, que esperaba próximamente un hijo y no podía criarlo, hicieron «anienca» con Hahim Eli y su mujer Soli Stallo para que ésta lo criara durante dieciocho meses, a partir de su nacimiento. Martín y Azibuena se comprometieron a pagarles diecisiete florines de oro en tres tandas, de seis a seis meses, y obligaron sus bienes a cumplirlo. Por su parte, Hahim y Soli se comprometieron a tener y cuidar bien a la criatura y obligaron también sus bienes; pero pusieron como condición que, si moría, tenían que «contar prorata, etc.» ${ }^{575}$.

La viuda Azibuena y su hermano converso habían resuelto la crianza del niño que iba a nacer, pero quedaba pendiente quién iba a ocuparse de la tutela de los menores y de la administración y gestión de sus bienes, teniendo en cuenta, además, que se estaba tratando un nuevo matrimonio de Azibuena con Salamon de la Fuent ${ }^{576}$.

Pasados unos meses, el 2 de diciembre, ante el clavario Salamon

574 Dicho notario y año, fols. $7 \mathrm{v}-8$.

575 Tomaron quinyan en poder de Simuel Pardo (dicho notario y año, fol. 45).

576 El 7 de diciembre de 1444, el tejedor Salamon de la Fuent recibió en comanda de Martín de la Plana cinco florines de oro, de los que respondió con su persona y bienes. Se acordó que los pagaría durante el siguiente mes de septiembre, "faziendose empero el casamiento entrel dito Salamon e Azibuena" (dicho notario y año, fol. 93). Pasaron los años y Salamon no pagó al converso y éste, el 1 de febrero de 1453, vendió al escudero Figueruela el contrato de los cinco florines que Salamon le debía, por otros cinco, que otorgó haber recibido con «el aliara» y de los que respondió con su persona y bienes (dicho notario, 1453, fols. 12-12v). 
Abenalcani y don Jehuda Frances, adelantados, el notario Pascual Contín y los testigos, comparecieron Martín, Simuel Atortox y la viuda Azibuena, como parientes propios y más cercanos de Solliqua, Estruguiqua y Alazariquo Ferrer, hijos de Alazar y Azibuena, y dijeron:

— «Senyores de adellantados, el dito Allazar Ferrer, quondam, es muerto intestado e ha dexado los ditos pupillos menores de hedat e por quanto vosotros soys padres, etc., vos requerimos deys tutores de las personas e bienes de aquestos, etc., como a vuestro officio se pertenesca, etc.».

Entonces los adelantados nombraron tutores de las personas y bienes de los menores a Simuel y a Azibuena, que aceptaron y, a su vez, nombraron fianza, según fuero y costumbre de judíos, a Sento Abencanyas, judío de la villa que estaba presente, "los quales tal fianza se establieron seyer, etc.»; y obligaron sus personas y bienes. Luego los adelantados empararon y dieron por emparados todos los bienes de los tutores y del fiador. A continuación, los tutores juraron sobre los diez mandamientos en poder de Juce de la Rabiça, que actuarían bien y lealmente, y ambos y el fiador tomaron «quinyan complido", según ley de judíos, en poder de éste ${ }^{577}$.

El necesario nombramiento de los tutores había dejado zanjada la cuestión de los pupilos, pero entre los bienes de Alazar había una parte a la que su viuda Azibuena tenía derecho y se hizo necesaria una nueva comparecencia que, como la anterior, tuvo lugar ante el mismo notario cristiano.

El 21 de diciembre ante el adelantado Jehuda Frances, compareció de nuevo el converso Martín de la Plana, como pariente más cercano de los hijos de Alazar y de su hermana Azibuena y, además, como procurador de ésta, y le dijo:

- «Jehuda, ya sabeys mas largament como Alazar Ferrer, quondam, tenia firmados a la dita Azibuena sobre todos sus bienes, assi mobles como sedientes, setanta florines, que vos requiero que vos entregeys a la dita mi hermana ...; en otra manera, en falta $e$ fadigua de vosotros, ella se entreguara e yo, como parient cerquano, la entreguare de los ditos bienes, e a escargo mio e cargo vuestro requiero".

${ }^{577}$ Dicho notario, 1444, fols. 91-91v. 
Después de que Martín pidiera al notario que levantara acta de su petición, respondió el adelantado "que era presto fazer lo que deviesse, etc.». A continuación, compareció Martín ante el adelantado Salamon Abenalcani y le hizo el mismo requerimiento, al que Salamon respondió con idénticas palabras que lo había hecho el adelantado Jehuda ${ }^{578}$.

Lo que fuera de Azibuena y de sus hijas Soliqua y Estruguiqua lo ignoro, pero no así lo que fue con el tiempo Alazarico, al que voy a referirme a continuación, no sin antes comentar el hecho de que fuera, precisamente, un notario cristiano quien diera fe de lo sucedido en la comparecencia y no un notario judío como en el caso de Cinha Cohen y de Alazarico y Reynica Alpullat; claro que no hay que olvidar que éstos tuvieron lugar en 1485 y 1486.

Alazar Ferrer, hijo de Alazar y Azibuena, vivía en unas casas de la judería que lindaban, en 1485, con las de Acach Abenforna y con las de Simuel Pardo. Era dueño también de un huerto que lindaba con las casas del labrador Pedro Moreno y de su mujer María Martínez ${ }^{579}$, y de una viña en Candenavas.

El 20 de octubre de 1485, Alazar y Acach de la Fuent - tal vez su hermanastro, si Azibuena llegó a casarse con Salamon de la Fuent- recibieron en comanda del escudero Martín de Caparrós ciento setenta sueldos, de los que respondieron los judíos con sus respectivas casas ${ }^{580}$.

Meses después, el 12 de febrero de 1486, Alazar Ferrer dio a medias su viña de Candenavas al labrador Juan de la Gorda, de Ricla, durante cuatro años a partir de ese día y con las siguientes condiciones: 1.a, cada año a su debido tiempo, Juan tenía que podarla, cavarla a su costa hasta el día de San Juan y regarla, si había agua para hacerlo; 2.", el año que Juan no la cavara, no se quedaría con el fruto; 3.', Alazar proporcionaría cada año un vendimiador a sus expensas, para ayudar a vendimiarla; 4.", Juan tenía que llevar la mitad de la cosecha hasta la propia casa de Alazar; 5.", la "vinyaderia" la pagarían los dos a medias, puesto que el fruto lo cogian a medias; y $6 .^{2}$, si Juan "echara algunos morgones» en la

578 Dicho notario y año, fol. 97.

579 L.A.APN., Miguel Contín, 1491, fol. 82 y 1492, fol. 80.

580 Dicho notario, 1485, fol. 81v. El 4 de febrero de 1486, Martín canceló la comanda (dicho notario, 1485, fol. $81 \mathrm{v}$, al margen). 
viña, Alazar le daría por cada dos un dinero. Con estas condiciones, Alazar prometió a Juan mantenerlo en pacífica posesión de la viña y obligó sus bienes a cumplirlo; y éste la recibió a medias durante el tiempo señalado y con las condiciones dichas, que prometió cumplir, y obligó también sus bienes a hacerlo ${ }^{581}$.

Ese mismo año Alazar Ferrer asistió a la reunión de la aljama que tuvo lugar el 11 de abril.

A finales de 1487 en Épila, concretamente el 1 de diciembre, Alazar Ferrer vendió a Juce Gotina, sastre judío de esta villa, los ciento veinte sueldos que Domingo Casado, vecino de Ricla, tenía suyos ${ }^{582}$. El precio, el mismo de la cantidad vendida, otorgó haberlo recibido ${ }^{583}$.

Es posible que Alazar, una vez conocido el edicto de expulsión, decidiera permanecer en la villa y convertirse porque, el 19 de julio de 1492, compró al sastre Sento Çarfati, junto con Mira, mujer de éste, y con Semahon Carillo, todos sus bienes muebles e inmuebles por ochocientos sueldos ${ }^{584}$.

[Continuará]

581 Dicho notario, 1486, fol. $18 \mathrm{v}$.

582 Según constaba en carta pública de comanda hecha en La Almunia [la fecha en blanco].

${ }^{583}$ Z.APN., Antón de Abiego, 1487, fols. 75-75v.

584 L.A.APN., Miguel Contín, 1492, fols. 80v-81. 